EQUILIBRIUM JOURNAL OF

CHEMICAL ENGINEERING

Homepage:https://jurnal.uns.ac.id/equilibrium

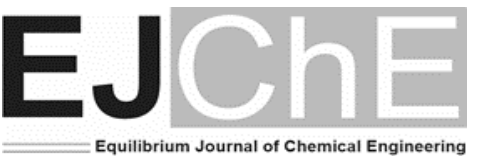

\title{
Synthesis of Syngas into Dimethyl Ether Using Cu-Zn-Al/ $\gamma$-Alumina Bifunctional Catalyst as an Environmentally Friendly Fuel for Substituting Liquified Petroleum Gas
}

\author{
Suratno Lourentius* \\ The Study Program of Engineer Profession, Engineering Faculty, Widya Mandala Surabaya Catholic University, Surabaya, Indonesia 60114 \\ *Corresponding author: suratno.lourentius@ukwms.ac.id \\ DOI: https://dx.doi.org/10.20961/equilibrium.v5i2.58479
}

Article History

Received: 15-11-2021, Accepted: 09-12-2021, Published: 18-01-2022

Keywords:

$\mathrm{Cu}-\mathrm{Zn}-\mathrm{Al} / \gamma$-alumina, dimethyl ether, environmentally friendly, syngas

\begin{abstract}
In order to meet the need for Liquified Petroleum Gas in Indonesia, which is currently around seventy percent of which is still imported, it is necessary to find a replacement. One of the efforts to replace the Liquified Petroleum Gas is by utilizing dimethyl ether which can be produced from coal as raw material. Coal can be catalytically converted to syngas and then syngas can be catalytically converted to dimethyl ether via a direct two-step or one-step route. This paper will discuss the one-step synthesis of dimethyl ether from syngas using $\mathrm{Cu}-\mathrm{Zn}-\mathrm{Al} / \gamma-\mathrm{Alumina}$ as a bifunctional catalyst. The syngas used consists of carbon monoxide and hydrogen with a mole ratio of 1:2. The conversion reaction was carried out in a fixed-bed reactor at the pressure of 40 bar, the temperature of $240-300^{\circ} \mathrm{C}$, and the space velocity of $29.3-32.7 \mathrm{~mL} / \mathrm{g}$ catalyst/minute. The highest conversion of $\mathrm{CO}$ that can be achieved is $90.08 \%$ at a temperature of $300{ }^{\circ} \mathrm{C}$ and the space velocity of $29.3 \mathrm{~mL} / \mathrm{g}$ catalyst/minute. The synthesis product was analyzed using GC. The dimethyl ether is an environmentally friendly fuel and non-toxic compound that does not destroy ozone, does not contain sulfur, and has a calorific value of about $30.5 \mathrm{MJ} / \mathrm{kg}$ which is lower than $50.56 \mathrm{MJ} / \mathrm{kg}$.
\end{abstract}

\section{INTRODUCTION}

The need for primary gas energy in Indonesia also includes the consumption of Liquified Petroleum Gas (LPG) which is met from LPG refinery production and LPG imports. In 2018, LPG consumption reached 7.5 million tons, which was met by domestic LPG production of 2 million tons (26 \%) and LPG imports of 5.5 million tons (74 \%). The success of the kerosene to LPG conversion program has increased LPG consumption while the supply of LPG from LPG refineries and domestic oil refineries is limited. The increase in consumption of LPG especially subsidized $3 \mathrm{~kg}$ LPG, needs to be anticipated by the government of the Republic of Indonesia because the subsidized $3 \mathrm{~kg}$ LPG is widely used by non-low-income people. To reduce the increasing volume of LPG imports, the government of the Republic of Indonesia is currently formulating a program to substitute LPG with Dimethyl Ether (DME) from coal and replace LPG with induction stoves [1].

DME produced from coal is carried out through the conversion stage of coal into Synthesis gas (syngas). Conversion of syngas to DME can be done through 2 routes. The first route is through two stages of syngas conversion to methanol followed by conversion of methanol to DME and the second route is only one stage of direct syngas conversion to DME. It is clear that the conversion of syngas to single-stage DME will be more prospective to implement because the process is simpler and the equipment investment costs are lower. The author wants to investigate the bifunctional catalyst for the conversion of syngas to DME and the reaction conditions. On the other hand, Indonesia's coal reserves reached 26.2 billion tons. With coal production of 461 million tons last year, the age of coal reserves is still 56 years if it is assumed that no new reserves are found. In addition to coal reserves, there are also coal resources which are recorded at 124.6 billion tons. Of this amount, 97 million tons are used for domestic purposes (Domestic Market Obligation/DMO). The trend of domestic coal utilization always increases from year to year. The Ministry of Energy and Mineral Resources of the Republic of Indonesia (2018) reports that as of 2013 the utilization of coal has only been 72 million tons, then to 97 million tons in 2017 with details of 2014 (76 million tons), 2015 (86 million tons) and 2016 (91 million tons). million tons) [2]. In the manufacture of syngas from coal, the highest efficiency is found in the entrained-bed gasifier process (Winkler 
Process) which reaches 95 percent, but the weakness is that the operating temperature is very high, namely 1500 $-1800{ }^{\circ} \mathrm{C}$. The lowest process temperature is found in the fluidized-bed process (Kopper Totzek Process) which is around $800-900{ }^{\circ} \mathrm{C}$, but the output (yield) is less than $95 \%$. The composition of the synthetic gas produced from this coal is hydrogen gas $\left(\mathrm{H}_{2}\right)$ ranging from $10-20 \%$ and carbon monoxide (CO) ranging from $15-30 \%$ [3]. One of the syngas is produced from the partial oxidation reaction of methane. This reaction is somewhat exothermic, which differs from the highly exothermic conditions of the steam reforming process and proceeds according to the reaction equation (1):

$$
\mathrm{CH}_{4}+\frac{1}{2} \mathrm{O}_{2} \stackrel{\text { catalyst }}{\Longleftrightarrow} \mathrm{CO}+2 \mathrm{H}_{2}
$$

Under standard conditions (298 K) the heat of reaction is $\Delta \mathrm{H}_{0}^{0}=-0.355 \mathrm{~kJ} / \mathrm{mol}$ and the Gibbs free energy is $\Delta \mathrm{G}^{0}=-86.53 \mathrm{~kJ} / \mathrm{mol}$. This reaction mechanism can produce syngas stoichiometrically for the synthesis of methanol in one step. Furthermore, DME can be synthesized in two ways. First, DME was synthesized in two steps, namely the catalytic reaction of methanol formation and followed by the dehydration reaction of methanol to DME. Cheng and Kung, using a lanthanide ruthenium oxide or alumina-supported ruthenium catalyst for the conversion of syngas to methanol at $775{ }^{\circ} \mathrm{C}$ obtained a reaction conversion of $94 \%$ and a selectivity of $97 \%$ [4]. The synthesis of methanol at low pressure was originally introduced by Imperial Chemical Industries (ICI) using a CuO-ZnO- $\mathrm{Al}_{2} \mathrm{O}_{3}$ catalyst which was carried out at a pressure of 5-10 MPa and a temperature of $200-280{ }^{\circ} \mathrm{C}$ [5] with the reaction equation (2):

$$
\mathrm{CO}+2 \mathrm{H}_{2} \stackrel{\text { catalyst }}{\Longleftrightarrow} \mathrm{CH}_{3} \mathrm{OH}
$$

Furthermore, the dehydration reaction of methanol to DME takes place according to reaction equation (3) as follows:

$$
2 \mathrm{CH}_{3} \mathrm{OH} \stackrel{\text { catalyst }}{\Longleftrightarrow} \mathrm{CH}_{3} \mathrm{OCH}_{3}+\mathrm{H}_{2} \mathrm{O}
$$

The reaction takes place in the gas phase with the heat of reaction is $\Delta \mathrm{H}_{\mathrm{f} 600 \mathrm{~K}}=-20.59 \mathrm{~kJ} / \mathrm{mole}$ and the Gibbs free energy is $\Delta \mathrm{G}_{\mathrm{f} 600 \mathrm{~K}}=-10.71 \mathrm{~kJ} / \mathrm{mole}$. The catalytic conversion of methanol to DME has been investigated by $\mathrm{Xu}$ et al., 1997, that by using a $10 \%$ by weight Pd/Cab-O-Sil catalyst at $225{ }^{\circ} \mathrm{C}$ for 10 minutes, a $27.5 \%$ methanol conversion was achieved with a DME selectivity of $78.5 \%$ with the result addition to carbon monoxide and methane and after the reaction lasted for about 4.5 hours the methanol conversion decreased from 27.5 to $16.5 \%$, while the selectivity of DME slightly decreased [6]. Meanwhile, Moreno-Castilla et al (2001) observed that the catalyst prepared from activated carbon oxidized with $\left(\mathrm{NH}_{4}\right)_{2} \mathrm{~S}_{2} \mathrm{O}_{8}$ had the strongest and most active group for dehydration of methanol at $453 \mathrm{~K}$ and the activation energy, $\mathrm{E}_{\mathrm{a}}=85.5 \mathrm{~kJ} / \mathrm{mole}$ and $12.61 \%$ carbon monoxide conversion was achieved with a reaction rate of $27 \times 10^{-6} \mathrm{~mole} / \mathrm{g}$ catalyst/minute [7]. The second method is the onestep synthesis of DME from syngas according to reaction equation (4) as follows:

$$
2 \mathrm{CO}+4 \mathrm{H}_{2} \stackrel{\text { catalyst }}{\Longleftrightarrow} \mathrm{CH}_{3} \mathrm{OCH}_{3}+\mathrm{H}_{2} \mathrm{O}
$$

The reaction takes place in the gas phase with the heat of reaction is $\Delta \mathrm{H}_{\mathrm{f} 600 \mathrm{~K}}=-35.31 \mathrm{~kJ} / \mathrm{mole}$ and the Gibbs free energy is $\Delta \mathrm{G}_{\mathrm{f} 600 \mathrm{~K}}=+79.97 \mathrm{~kJ} / \mathrm{mole}$. Furthermore, Sofianos and Scurrell (1991) used a $\mathrm{Zn}-\mathrm{Al} / \gamma-\mathrm{Al}_{2} \mathrm{O}_{3}$ catalyst prepared by the coprecipitated method and the conversion was carried out at a pressure of $4 \mathrm{MPa}$, the temperature of $300{ }^{\circ} \mathrm{C}$, the mole $\mathrm{H}_{2} / \mathrm{CO}$ ratio of about $2 / 1$ and the GHSV $=16,000 \mathrm{~h}^{-1}$, achieved $\mathrm{CO}$ conversion ranging from $50-60 \%$ [8]. Li et al (1996) used a catalyst prepared by $\mathrm{Cu}-\mathrm{Zn}$ coprecipitation with $\mathrm{Na}_{2} \mathrm{AlO}_{2}$, pressure $3 \mathrm{MPa}$, temperature $270{ }^{\circ} \mathrm{C}$, GHSV $=2,000 \mathrm{~h}^{-1}$ and a mole ratio of $\mathrm{H}_{2} / \mathrm{CO} / \mathrm{CO}_{2}$ around $64 / 31 / 5$ achieved CO conversion of $63.8 \%$ and DME yield of $43.7 \%$ [9]. Meanwhile, Ge et al. (1998) used one of two types of catalyst prepared by the co-precipitating sedimentation method, namely CuO-ZnO- $\mathrm{Al}_{2} \mathrm{O}_{3} / \mathrm{HZMS}-5$ and $\mathrm{CuO}-\mathrm{ZnO}-\mathrm{Al}_{2} \mathrm{O}_{3} / \mathrm{HSY}$ at pressure of $4 \mathrm{MPa}$, temperature of $290{ }^{\circ} \mathrm{C}$, GHSV $=1,500 \mathrm{~h}^{-1}$ mole ratio of feed $\mathrm{H}_{2} / \mathrm{CO}$ of about 2 and $\mathrm{CO}_{2}$ of about $5 \%$ achieved CO conversion $=89 \%$ and DME selectivity = $99 \%$ [10]. Furthermore, Takeguchi et al (2000) studied the effect of solid acid properties on the conversion of syngas to DME on various hybrid catalysts and reported that the catalysts composed of silica-rich methanol and silica-alumina synthesis catalysts were prepared by uniform gelation method at a temperature of $270{ }^{\circ} \mathrm{C}, 5 \mathrm{MPa}$. , GHSV $4200 \mathrm{~h}^{-1}$ and mole ratio percent feed $\mathrm{H}_{2} / \mathrm{CO} / \mathrm{CO}_{2}$ ranged from $67 / 30 / 3$ achieved DME yield of $55.5 \%$ with DME selectivity of $93.5 \%$ [11]. Meanwhile, Omata et al (2002) studied the synthesis of DME at low pressure with a copper-based hybrid catalyst prepared by 
the oxalate-ethanol method with a temperature gradient reactor reported that at pressures ranging from 1-5 MPa and temperatures ranging from 498-550 K, CO conversion was achieved around of $90 \%$ [12]. Furthermore, Sun et al (2003) used a bifunctional catalyst prepared by the coprecipitating sedimentation method under process conditions; temperature $250{ }^{\circ} \mathrm{C}$, pressure $3 \mathrm{MPa}$, mole ratio percent feed $\mathrm{CO} / \mathrm{CO}_{2} / \mathrm{H}_{2}$ of $30 / 3 / 67$, and space velocity (SV) 1,500 $\mathrm{h}^{-1}$ obtained DME selectivity of $83.12 \%$ and CO conversion of $72.79 \%$ [13]. Meanwhile, Ohno (2002) synthesized DME using the catalyst from the mixture of active metal Co-Zn-Al in solvent wax of the slurry reactor at the temperature of $280{ }^{\circ} \mathrm{C}$, the pressure of $5 \mathrm{MPa}$ and the mole ratio of $\mathrm{CO} / \mathrm{H}_{2}$ of $1 / 1$. The reaction proceeds according to equation (5) as follows [14]:

$$
3 \mathrm{CO}+3 \mathrm{H}_{2} \stackrel{\text { catalyst }}{\Longleftrightarrow} \mathrm{CH}_{3} \mathrm{OCH}_{3}+\mathrm{CO}_{2}
$$

with the heat of reaction is $\Delta \mathrm{H}_{\mathrm{R} 553 \mathrm{~K}}=-465 \mathrm{~kJ} / \mathrm{mole}$ and the Gibbs free energy is $\Delta \mathrm{G}_{\mathrm{R}} 533 \mathrm{~K}=-287 \mathrm{~kJ} / \mathrm{mole}$. From the description above, the author synthesizes one-step DME according to the reaction equation (4). The following review of thermodynamic aspects is intended to estimate the equilibrium $\mathrm{CO}$ conversion based on temperature and pressure conditions. Based on the thermodynamic aspect based on reaction (4), the stoichiometric coefficient value of equation (4) is $v=(1+1)-(2+4)=-4$. The enthalpy of formation $\left(\Delta \mathrm{H}_{\mathrm{f}}^{o}\right)$ and Gibbs free energy $\left(\Delta \mathrm{G}_{\mathrm{f}}^{\mathrm{o}}\right)$ at a standard temperature of $298 \mathrm{~K}$, as well as the constants in the equation for the relationship between the temperature on the heat capacity is $\mathrm{C}_{\mathrm{p}}^{\mathrm{o}}=\mathrm{A}+\mathrm{BT}+\mathrm{CT}^{2}+\mathrm{DT}^{3}$ are shown in Table 1 as follows [15]:

Tabel 1. The value of $\Delta \mathrm{H}_{\mathrm{f}}^{\mathrm{o}}, \Delta \mathrm{G}_{\mathrm{f}}^{\mathrm{o}}$, and the constants of $\mathrm{A}, \mathrm{B}, \mathrm{C}$, and $\mathrm{D}$

\begin{tabular}{llccccc}
\hline Compound & \multicolumn{1}{c}{$\begin{array}{c}\Delta \mathrm{H}_{\mathrm{f}}^{\mathrm{o}}, \\
\mathrm{J} / \mathrm{mole}\end{array}$} & $\begin{array}{c}\Delta \mathrm{G}_{\mathrm{f}}^{\mathrm{o}}, \\
\mathrm{J} / \mathrm{mole}\end{array}$ & $\mathrm{A}$ & $\mathrm{B}$ & $\mathrm{C}$ & $\mathrm{D}$ \\
\hline $\mathrm{CO}$ & $-1.106 \mathrm{E}+05$ & $-1.374 \mathrm{E}+05$ & $3.087 \mathrm{E}+01$ & $-1.285 \mathrm{E}-02$ & $2.789 \mathrm{E}-05$ & $-1.272 \mathrm{E}-08$ \\
$\mathrm{H}_{2}$ & $0.000 \mathrm{E}+00$ & $0.000 \mathrm{E}+00$ & $2.714 \mathrm{E}+01$ & $9.273 \mathrm{E}-03$ & $-1.380 \mathrm{E}-05$ & $7.645 \mathrm{E}-09$ \\
$\mathrm{CH}_{3} \mathrm{OCH} H_{3}$ & $-1.842 \mathrm{E}+05$ & $-1.130 \mathrm{E}+05$ & $1.702 \mathrm{E}+01$ & $1.791 \mathrm{E}-01$ & $-5.234 \mathrm{E}-05$ & $-1.918 \mathrm{E}-09$ \\
$\mathrm{H}_{2} \mathrm{O}$ & $-2.420 \mathrm{E}+05$ & $-2.288 \mathrm{E}+05$ & $3.224 \mathrm{E}+01$ & $1.924 \mathrm{E}-03$ & $1.055 \mathrm{E}-05$ & $-3.596 \mathrm{E}-09$ \\
\hline
\end{tabular}

Based on the data from Table 1, it can be used to calculate the Gibbs free energy of reaction (4) with equations (6) to (9) as follows [16]:

$\frac{\Delta G^{o}}{R T}=\frac{\Delta G_{o}^{o}-\Delta H_{o}^{o}}{R T_{o}}+\frac{\Delta H_{o}^{o}}{R T}+\frac{1}{T} \int_{T_{o}}^{T} \frac{\Delta C_{p}^{o}}{R} d T-\int_{T_{o}}^{T} \frac{\Delta C_{p}^{o}}{R} \frac{d T}{T}$

$\Delta \mathrm{C}_{\mathrm{p}}^{\mathrm{o}}=\Delta \mathrm{A}+\Delta \mathrm{BT}+\Delta \mathrm{CT}^{2}+\Delta \mathrm{DT}^{3}$

$\int_{\mathrm{T}_{\mathrm{o}}}^{\mathrm{T}} \frac{\Delta \mathrm{C}_{\mathrm{p}}^{\mathrm{o}}}{\mathrm{R}} \mathrm{dT}=\frac{1}{\mathrm{R}}\left\{\Delta \mathrm{AT}_{0}(\tau-1)+\frac{\Delta \mathrm{B}}{2} \mathrm{~T}_{0}^{2}\left(\tau^{2}-1\right)+\frac{\Delta \mathrm{C}}{3} \mathrm{~T}_{0}^{3}\left(\tau^{3}-1\right)+\frac{\Delta \mathrm{D}}{4} \mathrm{~T}_{0}^{4}\left(\tau^{4}-1\right)\right\}$

$\int_{\mathrm{T}_{\mathrm{o}}}^{\mathrm{T}} \frac{\Delta \mathrm{C}_{\mathrm{P}}^{\mathrm{o}}}{\mathrm{R}} \frac{\mathrm{dT}}{\mathrm{T}}=\frac{1}{\mathrm{R}}\left\{\Delta \mathrm{Aln} \tau+\Delta \mathrm{BT}_{0}(\tau-1)+\frac{\Delta \mathrm{C}}{2} \mathrm{~T}_{0}^{2}\left(\tau^{2}-1\right)+\frac{\Delta \mathrm{D}}{3} \mathrm{~T}_{0}^{3}\left(\tau^{3}-1\right)\right\}$

The values of $\Delta \mathrm{H}_{0}^{0}, \Delta \mathrm{G}_{0}^{0}, \Delta \mathrm{A}, \Delta \mathrm{B}, \Delta \mathrm{C}$ and $\Delta \mathrm{D}$ are each the difference from the sum of the values of the product components minus the sum of the values of the respective reactant components that are $\Delta \mathrm{H}_{0}^{0}=-205,000 \mathrm{~J} / \mathrm{mole}$, $\Delta \mathrm{G}_{0}^{0}=-67,000 \mathrm{~J} / \mathrm{mole}, \Delta \mathrm{A}=-1,21 \mathrm{E}+02, \Delta \mathrm{B}=-1,7 \mathrm{E}-01, \Delta \mathrm{C}=-4,24 \mathrm{E}-05$, and $\Delta \mathrm{D}=-1,07 \mathrm{E}-08$. Furthermore, the reaction equilibrium constant with the pressure term is calculated by the following equation (10)[16]:

$\mathrm{K}_{\mathrm{p}}=\exp \left(\frac{-\Delta \mathrm{G}^{0}}{\mathrm{RT}}\right)$

The composition of the reactants and reaction products in the reaction equilibrium can be calculated based on the assumption that initially, the reactants contain 1 mole of reacting $\mathrm{CO}$ and 2 moles of reacting $\mathrm{H}_{2}$ and at equilibrium, the number of moles of $\mathrm{CH}_{3} \mathrm{OCH}_{3}$ and $\mathrm{H}_{2} \mathrm{O}$ are $0<\varepsilon<0.5$ moles, respectively. The equilibrium composition of each compound is presented in Table 2 as follows: composition of each compound is presented in 
Table 2 as follows:

Table 2. Equilibrium composition of each compound in the DME synthesis reaction (5) including the value of critical pressure (PC), critical temperature (TC) and accentric factor $(\omega)$ [15]

\begin{tabular}{lllllll}
\hline Compound & $\begin{array}{l}\text { Initial Number } \\
\text { of mole }\end{array}$ & $\begin{array}{l}\text { Number of mole } \\
\text { in equilibrium }\end{array}$ & $\begin{array}{l}\text { Mole fraction, } \\
\mathrm{y}_{\mathrm{i}}\end{array}$ & $\mathrm{P}_{\mathrm{C}}, \mathrm{Bar}$ & $\mathrm{T}_{\mathrm{C}}, \mathrm{K}$ & $\omega$ \\
\hline $\mathrm{CO}$ & 1 & $1-2 \varepsilon$ & $(1-2 \varepsilon) /(3-4 \varepsilon)$ & 34,99 & 132,90 & 0,048 \\
$\mathrm{H}_{2}$ & 2 & $2-4 \varepsilon$ & $(2-4 \varepsilon) /(3-4 \varepsilon)$ & 13,13 & 33,19 & $-0,216$ \\
$\mathrm{CH}_{3} \mathrm{OCH}_{3}$ & 0 & $\varepsilon$ & $\varepsilon /(3-4 \varepsilon)$ & 52,40 & 400,00 & 0,200 \\
$\mathrm{H}_{2} \mathrm{O}$ & 0 & $\varepsilon$ & $\varepsilon /(3-4 \varepsilon)$ & 220,55 & 647,10 & 0,345 \\
Total & 3 & $3-4 \varepsilon$ & 1 & & & \\
\end{tabular}

The equilibrium equation in terms of mole fraction in DME synthesis is shown by equations (11) to (12) as follows:

$$
\begin{aligned}
& \frac{\varepsilon^{2}(3-4 \varepsilon)^{4}}{(1-2 \varepsilon)^{2}(2-4 \varepsilon)^{4}} K_{\phi}-\left(\frac{P}{P_{0}}\right)^{4} K_{P}=f(\varepsilon)=0 \\
& K_{\phi}=\frac{\phi_{\mathrm{CH}_{3} \mathrm{OCH}_{3} \phi_{\mathrm{H}_{2} \mathrm{O}}}}{\phi_{\mathrm{CO}}^{2} \phi_{\mathrm{H}_{2}}^{4}}
\end{aligned}
$$

The value for each component is calculated by equation (13) as follows [16]:

$\phi=\exp \left[\frac{P_{r}}{T_{r}}\left(B^{0}+\omega B^{1}\right)\right]$

where: $\mathrm{P}_{\mathrm{r}}=\mathrm{P} / \mathrm{P}_{\mathrm{C}}, \mathrm{T}_{\mathrm{r}}=\mathrm{T} / \mathrm{T}_{\mathrm{C}}, \mathrm{B}^{0}=0.083-0.422 / \mathrm{T}_{\mathrm{r}}^{1.6}, \mathrm{~B}^{1}=0.139-0.172 / \mathrm{T}_{\mathrm{r}}^{0.172}$

From the available data, based on equation (11), it can be calculated the value of $\varepsilon$, the number of moles in equilibrium conditions and the conversion of the CO reaction. In this investigation, the review of the thermodynamic aspects was also carried out on the reaction equation (5).

Based on the description above, it is deemed necessary to investigate with the following objectives:

1. Preparing and characterizing the catalyst of $\mathrm{Cu}-\mathrm{Zn}-\mathrm{Al} / \gamma$-Alumina;

2. Testing the performance of $\mathrm{Cu}-\mathrm{Zn}-\mathrm{Al} / \gamma$-Alumina catalyst for conversion of syngas into DME at the pressure of 40 bar and determining relatively good catalytic reaction conditions for syngas conversion to DME.

\section{MATERIALS AND METHODS}

\subsection{The materials}

As a support material is $\gamma$-alumina with a high specific surface area of about $180 \mathrm{~m}^{2} / \mathrm{gram}$ and is relatively stable at high temperature. Furthermore, the active metals are copper, zinc and aluminum which are impregnated from the nitrate salts of copper nitrate, zinc nitrate and aluminum nitrate. All the salt is obtained from PT. Merck Indonesia Tbk. The gases needed as reactants are Ultra High Purity hydrogen (UHP), High Purity carbon monoxide (HP) and High Purity nitrogen (HP) which are all obtained from PT Aneka Gas Industri Tbk Surabaya.

\subsection{The Apparatus}

The apparatus used in this research are the set of apparatus for catalyst preparation, the set of apparatus for calcination and reduction of catalysts, the set of the instrument of X-Ray Diffraction (XRD) and Inductively Coupled Plasma (ICP), the set of instruments for catalyst characterization, the set of fixed bed reactor for conversion of syngas to DME, and the set of Gas Chromatography (GC) instruments with a Thermal Conductivity Detector (TCD) and GC with a Flame Ionization Detector (FID) detector for analysis of the composition of the reactants and products of the reactor. 


\subsection{The step of preparation of the bifunctional catalyst}

With reference to Shikada et al (2000) a bifunctional Cu-Zn-Al/ $\gamma$-Alumina catalyst was prepared in the following four sub-steps [17]:

\subsubsection{The sub-step of impregnation of the metals}

The active metals were impregnated by mixing a solution of cupric nitrate, zinc nitrate and aluminum nitrate with a certain concentration and volume into a solution of $\gamma$-alumina with a certain weight and then the solution was stirred at room temperature for about 1 hour. The solution was then evaporated in a water bath at a temperature of $80^{\circ} \mathrm{C}$ while stirring until a paste was formed.

\subsubsection{The sub-step of filtration and drying}

The paste was then filtered through Whatman filter paper No. 42 using vacuum pump to separate the material from the filtrate. The solids were then dried in an oven at $120{ }^{\circ} \mathrm{C}$ for 42 hours.

\subsubsection{The sub-step of calcination}

The material to be calcined is placed in a porcelain crucible and then put into a horizontal furnace. The remaining space in the furnace is filled with glass wool. The temperature sensor is placed right in the middle of the material. The furnace is turned on until the temperature reaches $350{ }^{\circ} \mathrm{C}$ and the temperature is controlled by a temperature controller, while inert nitrogen gas is flowed at a rate of $100 \mathrm{~mL} /$ minute for 6 hours. At this sub-step, the reaction of the decomposition of the nitrate salts into metal oxides takes place with the following reaction equations:

$$
\begin{aligned}
& \mathrm{Cu}\left(\mathrm{NO}_{3}\right)_{2}(\mathrm{~s}) \rightarrow \mathrm{CuO}(\mathrm{s})+\mathrm{O}_{2}(\mathrm{~g})+2 \mathrm{NO}_{2}(\mathrm{~g}) \\
& \mathrm{Zn}\left(\mathrm{NO}_{3}\right)_{2}(\mathrm{~s}) \rightarrow \mathrm{ZnO}(\mathrm{s})+\mathrm{O}_{2}(\mathrm{~g})+2 \mathrm{NO}_{2}(\mathrm{~g}) \\
& \mathrm{Al}\left(\mathrm{NO}_{3}\right)_{3}(\mathrm{~s}) \rightarrow \mathrm{Al}_{2} \mathrm{O}_{3}(\mathrm{~s})+3 / 2 \mathrm{O}_{2}(\mathrm{~g})+6 \mathrm{NO}_{2}(\mathrm{~g})
\end{aligned}
$$

\subsubsection{The sub-step of reduction and catalyst characterization}

The material to be calcined is placed in a porcelain crucible and then put into a horizontal furnace. The remaining space in the furnace is filled with glass wool. The temperature sensor is placed right in the middle of the material as it is done in the calcination sub-step. The calcined material was further reduced by flowing it with hydrogen gas at a speed of $100 \mathrm{~mL} /$ minute at $230{ }^{\circ} \mathrm{C}$ for 4 hours. In calcination, the reduction reaction takes place as follows:

$$
\begin{aligned}
& \mathrm{CuO}(\mathrm{s})+\mathrm{H}_{2}(\mathrm{~g}) \rightarrow \mathrm{Cu}(\mathrm{s})+\mathrm{H}_{2} \mathrm{O}(\mathrm{g}) \\
& \mathrm{ZnO}(\mathrm{s})+\mathrm{H}_{2}(\mathrm{~g}) \rightarrow \mathrm{Zn}(\mathrm{s})+\mathrm{H}_{2} \mathrm{O}(\mathrm{g}) \\
& \mathrm{Al}_{2} \mathrm{O}_{3}(\mathrm{~s})+3 \mathrm{H}_{2}(\mathrm{~g}) \rightarrow 2 \mathrm{Al}(\mathrm{s})+3 \mathrm{H}_{2} \mathrm{O}(\mathrm{g})
\end{aligned}
$$

The prepared catalyst was then tested with X-Ray Diffraction (XRD) equipment to identify the presence of active metals and then tested with Inductively Coupled Plasma (ICP) to determine the percent loading of the active metals in the catalyst Furthermore, the catalyst is stored in a desiccator.

\subsection{The procedure of conversion of Syngas to DME}

Syngas conversion was carried out in a fixed bed reactor with the conditions: molar ratio of carbon monoxide to hydrogen 1:2, the total flow rate of the gas mixture in the range of $87.9-97.7 \mathrm{~mL} / \mathrm{minute}$ (measured at pressures of $1 \mathrm{~atm}$ and $30{ }^{\circ} \mathrm{C}$ ), the reaction temperature in the range of $220-300{ }^{\circ} \mathrm{C}$, the weight of the catalyst is 3 grams and the reactor pressure is $40 \mathrm{bar}$. The inside diameter of the reactor is $9 \mathrm{~mm}$ and a length of $30 \mathrm{~cm}$ which is made of pyrex glass. The pyrex glass pipe is reinforced with stainless steel pipe with an outer diameter of $12.7 \mathrm{~mm}$. The 
reactor is equipped with a heating jacket of nickelin wire with a power of 750 watts. Then the CO conversion procedure is as follows:

1. Catalyst weighing 3 grams is inserted into the cylindrical part of the pyrex pipe and the rest of the room is filled with glass wool.

2. Carbon monoxide gas and hydrogen gas with a molar ratio of 1:2 are flowed by opening the regulator valve from their respective gas cylinders. The volumetric flowrate of each gas is measured by the CIGWELD metering valve, then the two gases are mixed in a mixing pipe in such a way that the molar ratio of carbon monoxide gas and hydrogen gas is a molar ratio of $1: 2$, and also the gas flow velocity is measured by a rotameter.

3. Before the reactor was heated, the gas mixture was accommodated in a $300 \mathrm{~mL}$ sampler for analysis of the mole fraction of its constituents using a TCD detector GC with a Molecular Sieve (MS) 5A column. Sampling was carried out at the temperature of $300{ }^{\circ} \mathrm{C}$ and the pressure of 1 bar.

4. Next, the reactor is heated with a heating jacket whose temperature can be controlled by a temperature controller and the temperature of the catalyst in the reactor is read with a thermoline temperature indicator. The pressure in the reactor is set at 40 bar with a Swagelok safety valve and the pressure is read with a Bourdon gauge manometer. Gas leaks at the tube joints are detected with a swagelok leak detector.

5. After the reactor temperature reaches a certain temperature and is stable, half an hour later the reaction gas after leaving the reactor is flashed at a pressure of 1 bar and a temperature of $30{ }^{\circ} \mathrm{C}$. Furthermore, the gas in the sampler was analyzed using a GC detector TCD with an MS 5A column to determine the composition of residual carbon monoxide and the same gas sample was analyzed using a GC detector FID with a porapax Q column to determine the composition of the formed DME and the composition of other components.

\section{RESULTS AND DISCUSSION}

3.1 The bifungsional catalyst of $\mathrm{Cu}$-Zn-Al/ $\gamma$-Alumina

From the diffractogram data, it can be seen that the presence of $\mathrm{Cu}$ metal indicated by peaks with an angle of $2 \theta$ is $43.23^{0}$ with IR $=100 \%, 50.37^{\circ}$ with IR $=34,52 \%$ and $73.95^{\circ} \mathrm{IR}=15,28 \%$. Furthermore, the presence of $\mathrm{Zn}$ metal in the form of Zincite ( $\mathrm{ZnO})$ was indicated by the peaks at an angle of $2 \theta$ which were $32.05^{\circ}$ with IR $=$ $18.04 \%, 36.54^{\circ}$ with IR $=33.21 \%$ and $66.24^{\circ}$ with $\mathrm{IR}=15.36 \%$. And finally the presence of Al metal in the form of $\mathrm{Al}_{2} \mathrm{O}_{3}$ indicated by the $2 \theta$ angle peaks is $32.38^{\circ}$ with IR $=26.22 \%$; $39.01^{0}$ with IR $=23.64 \% ; 50.47^{0}$ with IR $=40.02 \%$; and $66.25^{\circ}$ with IR $=15.36 \%$. And finally the presence of $\mathrm{Al}$ metal in the form of $\mathrm{Al}_{2} \mathrm{O}_{3}$ indicated by the $2 \theta$ angle peaks is $32.38^{\circ}$ with IR $=26.22 \%$; $39.01^{\circ}$ with IR $=23.64 \%$; $50.47^{0}$ with IR $=40.02 \%$; and $66.25^{0}$ with IR $=15.36 \%$. From the test with the Inductively Coupled Plasma Spectrometer (ICPS) type AAS instrument, this catalyst has a metal loading percentage of $\mathrm{Cu}=4.5 \%$; $\mathrm{Zn}=2.7 \%$ and $\mathrm{Al}=4.4 \%$. The total active metal loading percentage of $11.6 \%$ is normal and common for catalysts with a buffer whose maximum loading percentage is $12 \%$.

\subsection{Data analysis of product conversion of syngas to DME}

The carbon monoxide and hydrogen feed in a 1:2 mole ratio are pre-mixed in a mixer. The volumetric flowrate is measured by a regulator valve and a metering valve and the flow rate is measured with a rotameter. The volumetric feed rate data ranged from 87.9 to $97.7 \mathrm{~mL} /$ minute measured at $300{ }^{\circ} \mathrm{C}$ and a pressure of 1 bar or equivalent to space velocity (SV)=29-33 mL/g catalyst/minute. The pressure in the reactor is controlled by the safety valve. The product reaction gas leaving the reactor was flashed to atmospheric pressure and then cooled, furthermore the reaction gas was sampled with a $300 \mathrm{~mL}$ sampler for later analysis with the GC instrument. Likewise with the reactor feed. The presence of CO gas in the gas was analyzed with a TCD detector and MS 5A column, while the presence of DME was analyzed with an FID detector and a porapax Q column in the GC instrument. From the chromatogram figure, the presence of $\mathrm{CO}$ gas was found at a retention time of 4.065 minute. The reactor inlet feed has a composition in mole percent consisting of $\mathrm{CO}=33.475 \%$ and $\mathrm{H}_{2}=66.015 \%$. From the chromatogram data of the product analysis, it was found that DME appeared at a retention time of 1.10 minutes, and from the chromatogram data of other reactor products, it was found that the reactor product, in addition to containing residual $\mathrm{CO}$, also contained $\mathrm{H}_{2} \mathrm{O}$ and $\mathrm{CO}_{2}$ components. The presence of $\mathrm{CO}_{2}$ indicates that the reaction for the formation of DME is not single reaction according to reaction (4), but it follows by the side reaction , according to reaction (5). Since the reaction is not single reaction, it is necessary to define CO conversion, DME 
yield and DME selectivity. Conversion of $\mathrm{CO}$ is the number of moles of $\mathrm{CO}$ reacted/the number of moles of initial CO x 100\%; Yield DME is the number of moles of DME formed/the number of moles of initial CO x $100 \%$ and DME selectivity is the number of moles of DME/the number of moles of CO reacted x $100 \%$.

\subsection{Effect of Temperature on CO Conversion}

The effect of temperature on experimental $\mathrm{CO}$ conversion and equilibrium $\mathrm{CO}$ conversion is presented in Figure 1 as follows

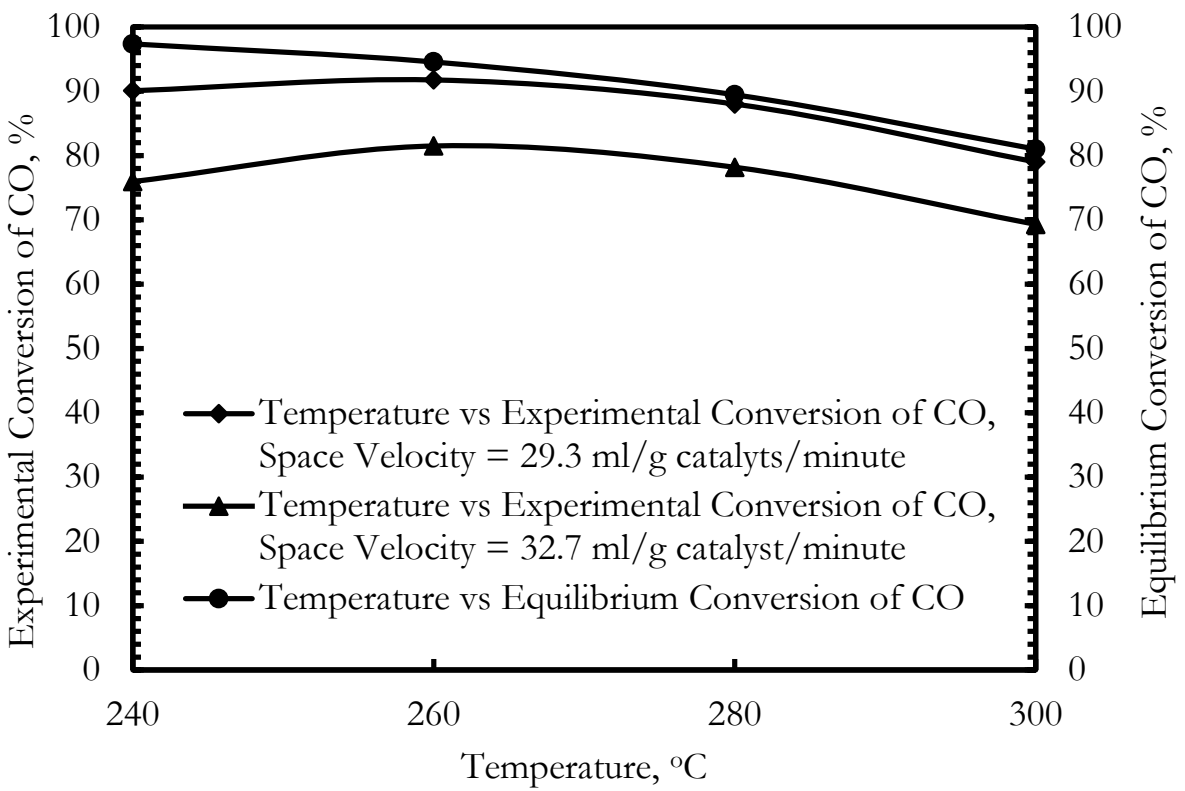

Figure 1. Relationship between temperature on Experimental CO Conversion and Equilibrium CO Conversion for both Space Velocity and $\mathrm{CO} / \mathrm{H}_{2}=1 / 2$ mole ratio

From Figure 1 it can be seen that the experimental $\mathrm{CO}$ conversion value is still smaller than the equilibrium $\mathrm{CO}$ conversion. This means that the reaction between $\mathrm{CO}$ and $\mathrm{H}_{2}$ with a mole ratio of $1 / 2$ is not singular but there is a side reaction. From the chromatogram data of the reaction products, both analyzed with TCD and FID detectors, it showed the presence of residual $\mathrm{CO}$ components, residual $\mathrm{H}_{2}, \mathrm{DME}, \mathrm{H}_{2} \mathrm{O}$ and $\mathrm{CO}_{2}$. This proves that the syngas synthesis reaction to DME is not singular but has side reactions according to the reaction equation (5). From the thermodynamic aspect for the temperature range under study, the equilibrium constant values for reaction (1) ranged from 64.20 to 2.71 and for reaction (5) ranged from 54.93 to 91.00 . This indicates that the potential for the formation of DME through reaction (2) is much greater than that of reaction (4). The equilibrium CO conversion in Figure 1 is the equilibrium CO conversion calculated based on the couple of reaction. As the temperature increases from 240 to $300{ }^{\circ} \mathrm{C}$, the equilibrium CO conversion will decrease from 97.4 to $81.0 \%$. This is because both reactions are exothermic with a heat value of reaction (4) $205 \mathrm{~kJ} / \mathrm{mole}$ and reaction (5) 246.2 $\mathrm{kJ} /$ mole both at a temperature of $298.15 \mathrm{~K}$. For an exothermic reaction based on Le Cathelier's principle, an increase in temperature will actually shift the reaction equilibrium shifts to the left. In addition, the effect of temperature on the experimental CO conversion showed the same pattern for the value of space velocity (29.3 to $32.7 \mathrm{~mL} / \mathrm{g}$ catalyst/minute), from a temperature of 240 to $260^{\circ} \mathrm{C}$, CO conversion would increase this indicates that the effect of chemical reaction kinetics more dominant than the effect of thermodynamic equilibrium. In addition, the activity of the $\gamma$-alumina buffered catalyst does occur at a temperature of about $260{ }^{\circ} \mathrm{C}$. However, in the temperature range of 260 to $300{ }^{\circ} \mathrm{C}$, it shows that with increasing temperature it will decrease CO conversion. This is because of in this temperature range the influence of thermodynamic equilibrium is more dominant than the influence of chemical reaction kinetics. Also keeping in mind that the DME formation reaction is a catalytic reaction in which there are at least 3 influences that affect the overall reaction speed, namely the mass transfer rate of the reactants from the gas body to the catalyst surface (adsorption rate), the surface reaction rate and the mass transfer rate of the products from the catalyst surface to the gas body by desorption. Of the three effects that control 
of overall rate of reaction is the rate of DME desorption from the catalyst surface to the gas body [18]. This condition will result in the decreased CO conversion. Also, with the increase in the value of space velocity from 29.3 to $32.7 \mathrm{~mL} / \mathrm{g}$ catalyst/minute, for the temperature range studied, it shows that the CO conversion value actually decreases. This is due to the fact that with the increase in the space velocity, the contact time between the reactants and the catalyst surface becomes shorter, so that the $\mathrm{CO}$ conversion will also decrease. The highest conversion in the temperature range studied was achieved at $260{ }^{\circ} \mathrm{C}$, namely at $\mathrm{CO}$ conversion $=90.08 \%$ and this is advantageous in terms of utility provision because high $\mathrm{CO}$ conversion can be achieved at relatively low temperatures.

\subsection{Effect of Temperature on Yield of DME and Selectivity of DME}

The effect of temperature on Yield of DME and Selectivity of DME selectivity is presented in Figure 2 as follows:

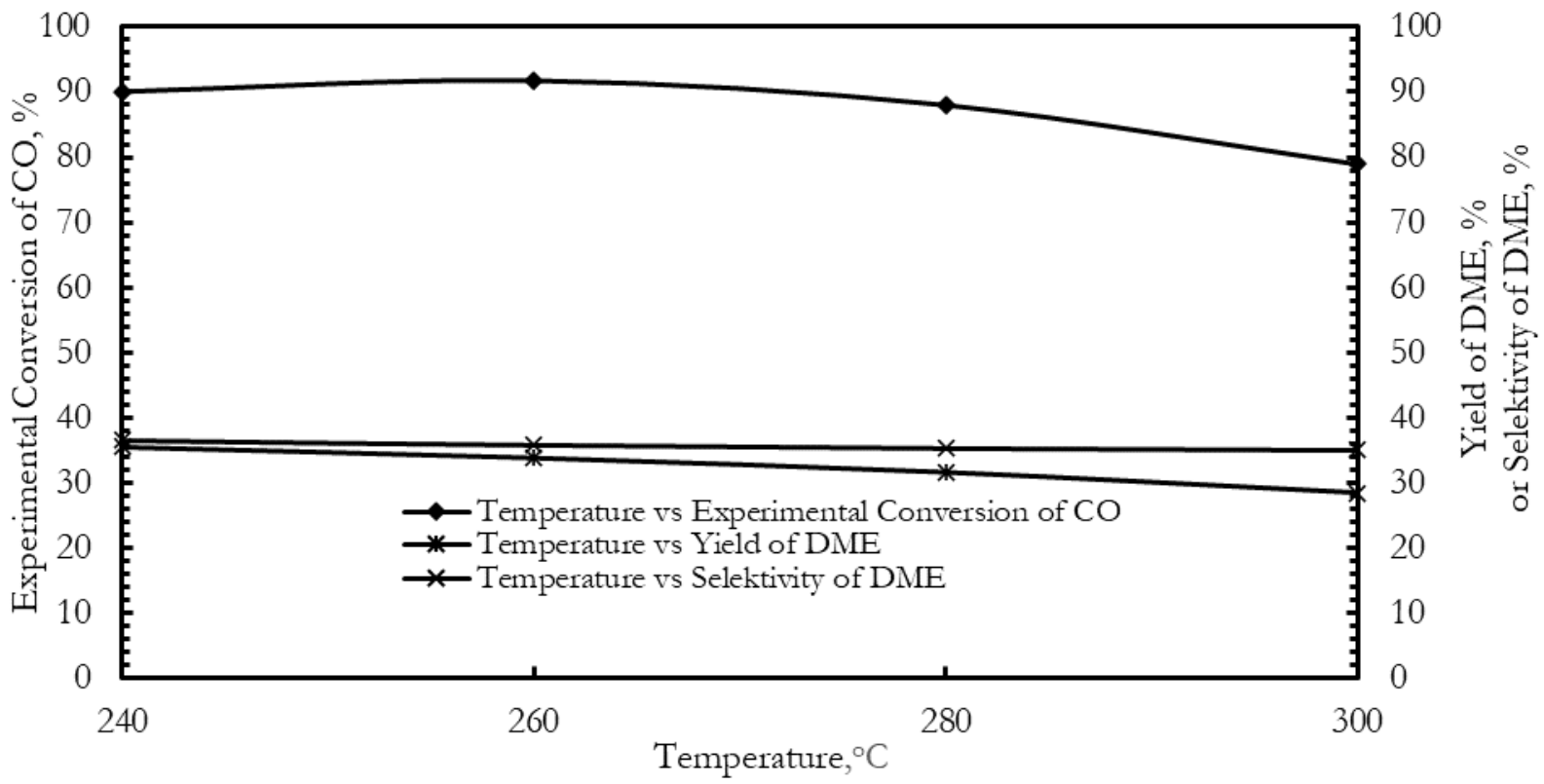

Figure 2. Relationship between temperature on Yield of DME and Selectivity of DME, CO/H2 mole ratio=1/2, Space Velocity $=29.3 \mathrm{~mL} / \mathrm{g}$ catalyst $/$ minute

From Figure 2, it can be seen that with increasing temperature both the Yield of DME and Selectivity of DME will decrease. It can be seen that the prepared catalyst is still not functioning properly, especially from its buffer function. From the high reaction $\mathrm{CO}$ conversion value, which is close to the thermodynamic equilibrium reaction conversion, it shows that the function of the catalyst-activating metals is functioning properly. However, this is not the case with the function of the $\gamma$-alumina catalyst support. With a mole ratio of $\mathrm{CO} / \mathrm{H} 2$ is $1 / 2$, it is originally expected that $\gamma$-alumina as a buffer could act as a triggering agent or trigger for the formation of water, so that reaction (4) will shift to the right and ultimately increase Yield of DME or Selectivity of DME. However, in reality the withdrawal of water by the $\gamma$-alumina catalyst support does not occur quickly, this is what triggers a side reaction with the same reactants to form $\mathrm{DME}$ and $\mathrm{CO}_{2}$ according to reaction equation (5).

Besides the fact that the reaction equation (5) has a higher reaction equilibrium constant value than the reaction equilibrium constant (4), and the slow desorption of DME from the catalyst surface will cause a low DME formation rate. The presence of a side reaction, namely reaction (5), made both the yield of DME and the selectivity of DME not high. It should also be noted that $\gamma$-alumina is amorphous which is susceptible due to the influence of high temperature so that it affects the stability of the catalyst. This is what causes that the higher the temperature, the lower the yield of DME and the selectivity of DME. The best yield of DME and selectivity of DME conditions 
were achieved at $240{ }^{\circ} \mathrm{C}$, namely yield of DME is $35.56 \%$ and selectivity of DME is $35.53 \%$. With the side reaction, it will result in side products that have no calorific value when burned, namely water and $\mathrm{CO}_{2}$.

DME after being separated from other reaction products has a calorific value of about $30.5 \mathrm{MJ} / \mathrm{kg}$ which is lower than the calorific value of LPG, which is $50.56 \mathrm{MJ} / \mathrm{kg}$. With this calorific value, DME can be used as a substitute for LPG. Because this DME compound does not bind to sulfur and does not contain compounds that can damage it, DME is environmentally friendly. The use of relatively new raw materials for the preparation of catalysts and the search for more accurate, prospective preparation methods and testing of catalysts on nitrogen sorption are expected to improve the performance of the prepared catalysts. As a comparison, the bifunctional catalyst was made from a mixture of two catalysts, namely commercial methanol synthesis catalyst and H-ZSM5 at a reactor pressure of 40 bar using a slurry reactor at a mole ratio of $\mathrm{CO} / \mathrm{H}_{2}$ is $1 / 2$, temperature $240{ }^{\circ} \mathrm{C}$ and space velocity of $500 \mathrm{~mL} / \mathrm{g}$ catalyst/hour obtained yield of DME is $65 \%$ and conversion of CO is $95 \%$ [19].

\section{CONCLUSION}

From the results of research and discussion, the following conclusions can be drawn:

1. The bifunctional catalyst prepared by $\mathrm{Cu}-\mathrm{Zn}-\mathrm{Al} / \gamma-\mathrm{Al}_{2} \mathrm{O}_{3}$ after analysis had a $\mathrm{Cu}$ loading percent $=4.5 \% ; \mathrm{Zn}=$ $2.7 \%$ and $\mathrm{Al}=4.4 \%$ with percent total metal loading $=11.6 \%$;

2. By the $\mathrm{CO} / \mathrm{H}_{2}$ at $1 / 2$ mole ratio, space velocity at $29.3 \mathrm{~mL} / \mathrm{g}$ catalyst/minute, temperature at $260{ }^{\circ} \mathrm{C}$, and fixed bed reactor pressure at 40 bar, the $\mathrm{CO}$ conversion is $90.08 \%$ which is still below of the equilibrium CO conversion of $97.4 \%$. At a temperature of $240{ }^{\circ} \mathrm{C}$ with other conditions being the same, the yield of DME is $35.57 \%$ and the selectivity of DME is $36.53 \%$ are achieved. DME does not contain sulfur, is non-toxic and free from ozone-depleting groups. It is environmentally friendly with a calorific value of $30.5 \mathrm{MJ} / \mathrm{kg}$ which is lower than the calorific value of LPG, which is $50.56 \mathrm{MJ} / \mathrm{kg}$.

\section{REFERENCES}

[1] Suharyati, S. H. Pambudi, J. L. Wibowo and N. I. Pratiwi, "Indonesia Energy Outlook 2019”, Jakarta, Indonesia: DEN Secretariat National, Energy Council, 2019

[2] Ministry of Energy and Mineral Resources, Republic of Indonesia, (2018) "Indonesia's Coal Reserves of 26 Billion Tons”, Available: https://www.esdm.go.id [Accessed: 21 Maret 2018]

[3] M. E. Harahap and E. W. Tjahjono, "Study of Synthetic Gas Manufacturing Process Technology from Coal and Prospects of Utilization in Downstream Industries”, M.P.I., vol. 10, no. 1, pp. 61-70, Apr, 2016

[4] W. Cheng and H. H. Kung, "Methanol Production and Use", New York: Marcel Dekker Inc., 1994, pp. 1132

[5] C. D. Holland and R. G. Antony., "Fundamental of Chemical Reation Enginering”, $2^{\text {nd }}$ ed., New Jersey, Prentice Hall International Editions, 1989, pp. 348-394

[6] M. Xu., D. W. Goodwan, and A. Battacharyya, "Catalytic Dehydration of Methanol to Dimethyl Ether (DME) Over Pd/Cab-O-Sil Catalyst”, Applied Catalysis A: General, vol 149, pp. 303-309, 1997

[7] C. Moreno-Castilla, F. Carrasco-Marin, C. Pajero-Perez and M. V. Lopez Ramon, "Dedydration of Methanol to Dimethyl Ether Catalyzed by Oxidized Activated Carbon With Varying Surface Acidic Character", Carbon, vol. 39, pp. 869-875, 2001

[8] A. C. Sofianos and M. S. Scurrell, "Conversion of Synthesis Gas to Dimethyl Ether Over Bifunctional Catalyst Systems”, Ind. Eng. Chem. Res., vol 30, pp. 2372-2378, 1991

[9] J. L. Li, X. G. Zhang and T. Inui, "Improvement in the Catalyst Activity for Direct Synthesis of Dimethyl Ether from Synthesis Gas Through Enhancing the Dispersion of $\mathrm{CuO} / \mathrm{ZnO} / \gamma-\mathrm{Al}_{2} \mathrm{O}_{3}$ in Hybrid Catalysts", Applied Catalysis A: General, vol. 147, pp. 23-33, 1996

[10] Q. Ge, Y. Huang, F. Qui and S. Li, "Bifunctional Catalyst for Conversion of Synthesis Gas to Dimethyl Ether”, Applied Catalysis A: General, vol. 167, pp. 23-30, 1998

[11] T. Takeguchi, K. Yanagisawa, T. Inui and M. Inoue, "Effect of The Property of Acid Upon Syngas-toDimethyl Ether Conversion on Hybrid Catalyst of Cu-Zn-Ga and Solid Acids", Applied Catalysts A: General, vol. 192, pp. 201-209, 2000

[12] K. Omata, Y. Watanabe, T. Umegaki, T. Ishguro, and G. Yamada, "Low Pressure DME Synthesis With CuBased Hybrid Catalysts Using Temperature Gradient Reactor”, Fuel, vol. 81, pp. 1605-1609, 2002

[13] K. Sun, W. Lu, F. Qui, S. Xu and X. Xu, "Direct Synthesis of DME Over Bifunctional Catalyst Surface 
Properties and Catalytics Performance”, Applied Catalysis A: General, vol. 252, pp. 243-249, 2003

[14] Y. Ohno, "New Clean Fuel Dimethyl Ether (DME) Synthesis Technology", The Paper Presented on Seminar about DME held in ITS Surabaya, pp. 1-27, Apr, 2002

[15] B. E. Poling, J. M. Prausnitz and J. P. O’Connell, “The Properties of Gases and Liquids”, 5 th ed., New York, The McGraw-Hill Companies, Inc., 2001, pp. A-1 - A-60

[16] J. M. Smith, H. C. Van Ness, and M. M. Abbott, "Introduction to Chemical Engineering Thermodynamics", 7th Ed., New York, The McGraw-Hill Companies, Inc, 2005, pp. 484-510

[17] T. Shikada, O. Yotaro, T. Ogawa, M. Mizoguchi, "Materal Method and Apparatus for Producing Dimethyl Ether”, US Patent 6147125, pp. 1-44, Nov., 2000

[18] S. Lourentius, "Kinetika Reaksi Katalitik Konversi Syngas Menjadi Dimethyl Ether”, Prosiding Seminar Nasional Teknik Kimia “Kejuangan” Universitas Pembangunan Nasional “Veteran”, Yogyakarta, 2008, pp. C10-1-C10-6

[19] G. R. Moradi, J. Ahmadpour, F. Yaripour, J. Wang, "Equilibrium calculations for direct synthesis of Dimethyl ether from syngas”, Can. J. Chem. Eng. 89:108-115, Feb, 2011 